\title{
REFLEKSI PENDIDIKAN FILSAFAT IDEALISME
}

\author{
Ali Mubin \\ alimubin1972@gmail.com \\ (Dosen Fakultas Agama Islam, Universitas Muhammadiyah Tangerang)
}

\begin{abstract}
Abstrak:
Filsafat Idealisme Plato menekankan pentingnya keunggulan pikiran (mind), roh (soul) atau jiwa (spirit) daripada hal-hal yang bersifat kebendaan atau material. Pokok pikiran filsafat Idealisme terdiri dari bahasan metafisika, epistimologi dan aksiologi. Bahwa refleksi pendidikan filsafat idealisme dalam praktek pendidikan yakni terlaksananya proses pendidikan dengan mendasarkan formulasi yang bertujuan untuk membentuk karakter, mengembangkan bakat atau kemampuan dasar, serta kebaikan sosial, kurikulum pendidikan ke arah pengembangan kemampuan nalar secara rasional dan pendidikan praktis, metode merupakan kunci bermain dalam mendidik dan yang diutamakan oleh idealisme adalah metode socratik/dialektika, peserta didik bebas untuk mengembangkan kepribadian, bakat dan kemampuan dasarnya, pendidik bertanggung jawab dalam menciptakan lingkungan pendidikan melalui kerja sama dengan lingkungan, peserta didik dan alam.
\end{abstract}

Kata kunci: Pendidikan, Filsafat, Idealisme.

\section{A. Pendahuluan}

Pendidikan sebagai upaya untuk memanusiakan manusia melalui human resource development memerlukan wawasan yang luas, seluas aspek kehidupan manusia itu sendiri. Karenanya masalah pendidikan tidak cukup hanya didasarkan pengalaman saja, melainkan dibutuhkan suatu pemikiran mendalam, pengkajian secara ilmiah dan penelitian yang up to date. Bahkan yang tidak kalah pentingnya pendidikan juga harus dibangun diatas fondasi discourse and philosophical analysis.

Pendekatan filosofis terhadap pendidikan adalah suatu pendekatan untuk memecahkan masalah-masalah pendidikan dengan menggunakan pendekatan filsafat. Sehingga pengetahuan atau teori pendidikan hasil dari pendekatan filsafat tersebut disebut dengan filsafat pendidikan. Pendidikan membutuhkan filsafat, karena masalah pendidikan tidak hanya menyangkut masalah pelaksanaan pendidikan semata yang hanya terbatas pada pengalaman, fakta-fakta yang dijangkau oleh inderawai, tetapi pendidikan juga akan berhadapan dengan fakta-fakta bersifat metafisik yang dalam hal ini hanya dapat dijangkau oleh ilmu filsafat. Masalahmasalah tersebut diantaranya adalah tujuan pendidikan yang bersumber dari tujuan hidup dan nilai-nilai kehidupan manusia.

Filsafat sebagai induk dari ilmu pengetahuan (the mother of knowledge) pada dasarnya bermaksud untuk menjawab seluruh problematika yang ada maupun yang mungkin ada dalam kehidupan manusia. Masalah yang berkaitan dengan trilogi metafisika, yaitu manusia, Tuhan dan alam beserta problematikanya menjadi issu utama yang menjadi kajian filsafat ${ }^{1}$.

Seiring dengan perkembagan dan perubahan yang terjadi di masyarakat, ternyata ada banyak berbagai masalah

\footnotetext{
${ }^{1}$ Mulyadhi Kartanegara, Menembus Batas Waktu, Panorama Filsafat Islam, Sebuah Refleksi Autobiografis (Bandung: Mizan, 2005), h. 124.
} 
kemanusiaan yang tidak mampu dijawab oleh filsafat. Maka lahirnya sebuah ilmu pengetahuan sesungguhnya merupakan jawaban atas kegagalan filsafat dalam menjawab problem kemanusiaan yang komplek dan universal. Dengan menggunakan cara kerjanya yang sistematis, universal dan radikal yang mengupas, menganalisa sesuatu secara mendalam ternyata filsafat sangat relevan dengan segala problematika hidup dan kehidupan manusia serta mampu menjadi perekat kembali antara berbagai macam disiplin ilmu yang terpisah kaitannya satu dengan yang lain ${ }^{2}$.

Penulis mencermati bahwa ternyata filsafat telah berkembang dan berubah dari mother of knowledge menjadi philosophical analysis yakni, analisa filosofis dalam memecahkan permasalahan dalam dunia ilmu pengetahuan dan kehidupan manusia yang nyata. Oleh karena itu, pada giliranya filsafat memiliki implikasi dalam konteks operasionalisasi pendidikan. Implementasi pendidikan juga banyak dipengaruhi oleh aliran-aliran filsafat pendidikan yang dikembangkan dengan perspektif filsafat. Jadi sesuai dengan pokok bahasan pada makalah ini penulis akan memfokuskan kajiannya pada kajian releksi pendidikan filsafat idealisme dan implementasinya dalam dunia pendikan dewasa ini.

\section{B. Pemikiran Filsafat Idealisme dalam Lintasan Sejarah}

Filsafat idealisme berasal dari Plato, yaitu filsuf Yunani yang hidup pada tahun 427-347 SM. Sebagaimana akar kata idealisme, awal mulanya berasal dari bahasa Yunani idea yang berarti pandangan (vision) atau kontemplasi.

\footnotetext{
${ }^{2}$ Jujun Suriasumantri, Ilmu Dalam Perspektif (Jakarta: PT Gramedia), h.35
}

Istilah ini pertama kali digunakan oleh filosof ahli matematika Jerman G. W. Leibniz pada awal abad ke-18 yang merujuk pada pemikiran Plato dan membedakannya dengan empirisisme. ${ }^{3}$

Idealisme ini digunakan sebagai nama untuk teori tentang ide-ide arketip (archetypal ideas) dan untuk doktrin epistemologis Rene Descartes dan John Locke yang menyatakan bahwa ide yang dalam doktrin ini berarti objek pemahaman manusia bersifat subjektif dan dimiliki secara pribadi. Pengertian idealisme di atas, yang meragukan eksistensi dunia materi, membuat istilah ini juga digunakan untuk akosmisme yang menganggap alam materi hanya sekedar proyeksi dari pikiran manusia dan immaterialisme yang menyatakan bahwa dunia materi tidak ada.

Ternyata, kata idealisme semakin populer setelah digunakan oleh Immanuel Kant yang menyebut teori pengetahuannya sebagai idealisme kritis atau idealisme transendental ${ }^{4}$. Dalam pengertian filsafati, idealisme adalah sistem filsafat yang menekankan pentingnya keunggulan pikiran (mind), roh (soul) atau jiwa (spirit) dari pada hal-hal yang bersifat kebendaan atau material. Pandangan-pandangan umum yang disepakati oleh para filsuf idealisme, yaitu: Jiwa (soul) manusia adalah unsur yang paling penting dalam kehidupan manusia dan hakikat akhir alam semesta yang pada dasarnya adalah nonmaterial. Sebagai sebuah aliran dalam filsafat, dapat penulis nyatakan idealisme telah

${ }^{3}$ A. Pablo Iannone, Dictionary of World Phylosophy (London \& New York: Routledge, 2001), h. 251. (dalam http/:nurohcmanceper.blogspot.com/2010).

${ }^{4}$ Kita bisa lihat dalam: Wilbur Long, Idealism, dalam Dagobert D.Runes, The Dictionary of Phylosophy (New York: Phylosophical Library, tt), h. $136 \quad$ (dalam http/:nurohcmanceper.blogspot.com/2010) 
menjelaskan bahwa pengetahuan itu tidak lain daripada kejadian dalam jiwa manusia, sedangkan kenyataan yang diketahui manusia itu terletak di luarnya. Sedangkan pemikiran filsafat menurut aliran idealisme adalah sebagai berikut:

\section{Metafisika Idealisme}

Metafisika adalah cabang filsafat yang mempelajari hakikat realitas (segala sesuatu yang ada) secara komprehensif. Menurut Idealisme hanya realitas spiritual, mental atau rohani yang nyata dan tidak berubah. Karena dengan hakikat realitas yang bersifat rohani, spiritual dan ideal itulah yang kekal dan abadi. Alam semesta adalah ekspresi dari sebuah kecerdasan yang sangat umum dari pikiran universal ${ }^{5}$.

Pemikiran Daniel U, tersebut bagi penganut idealisme adalah sebuah realitas yang diturunkan dari suatu substansi fundamental, adapun substansi fundamental itu sifatnya nonmaterial, yaitu pikiran/spirit/roh. Dan benda-benda yang bersifat material yang tampak nyata, sesungguhnya diturunkan dari pikiran/ spirit/roh. Di sisi lain, menurut para filsuf idealisme bahwa manusia hakikatnya bersifat spiritual/kejiwaan. Sementara itu menurut Plato, setiap manusia memiliki tiga bagian jiwa, yaitu nous (akal pikiran) yang merupakan daya rasional, thumos (semangat atau keberanian), dan epithumia (keinginan, kebutuhan atau nafsu).

Setelah penulis merenung, ternyata dari ketiga bagian jiwa tersebut akan muncul salah satunya yang dominan. Jadi, sebenarnya hakikat manusia bukanlah badannya, melainkan jiwa/spiritnya. Nah, sebagai makhluk yang bisa berfikir, manusia mampu memilih serta memiliki

${ }^{5}$ Baca: Allan C Ornstein \& Daniel U, An Introduction To The foundations of Education (Boston: Houghton Mifflin Company,1985), t.h. (dalam http/:nurohcman-ceper.blogspot.com/2010) kebebasan, hidup dengan suatu aturan moral yang jelas dan bertujuan yang lebih terarah.

Idealisme juga mengindentifikasi bahwa hakikat nyata dunia adalah berupa ide yang sifatnya rohani atau juga disebut intelegensi. Termasuk dalam paham idealisme ini adalah paham spiritualisme, rasionalisme dan supernaturalisme.

Secara absolut kenyataan yang sebenarnya adalah spiritual dan rohaniah, meskipun pada kenyataannya ada realita yang bersifat fisik tetapi sesungguhnya kenyataan rohanilah yang lebih dapat berperan.

\section{Epistemologi Idealisme}

Epistemologi adalah cabang filsafat yang mempelajari tentang hakikat pengetahuan. Menurut filsafat idealisme, proses mengetahui terjadi dalam pikiran, manusia memperoleh pengetahuan melalui berfikir dan intuisi (gerak hati). Beberapa filsuf percaya bahwa pengetahuan diperoleh dengan cara mengingat kembali (semua pengetahuan adalah sesuatu yang diingat kembali). Sehinggga mengetahui adalah memikirkan lembali gagasan laten, yakni yang sudah ada sejak lama dan abadi.

Adapun tentang teori pengetahuan, idealisme mengemukakan bahwa pengetahuan yang diperoleh melalui indera ternyata tidak pasti dan bahkan tidak lengkap karena dunia hanyalah merupakan tiruan belaka, sifatnya maya (maka sering dikenal dengan dunia maya) yang menyimpang dari kenyataan sebenarnya (seperti beredarnya informasi hoaks-pen).

Pengetahuan yang benar hanya diperoleh melalui intuisi dan pengingatan kembali melalui proses berpikir yang terarah. Kebenaran hanya mungkin dapat dicapai oleh manusia yang mempunyai akal pikiran yang cemerlang, jernih, murni dan 
itupun sebagian besar manusia hanya sampai pada tingkat berpendapat/ komentar, jarang sekali sampai pada tingkat menemukan teori baru secara murni.

\section{Aksiologi Idealisme}

Aksiologi adalah cabang filsafat yang mempelajari tentang hakikat nilai. Para filsuf idealisme sepakat bahwa nilai bersifat mutlak dan abadi ${ }^{6}$. Keabadian nilai yang dimaksud merupakan elaborasi dari dua jenis idealisme yakni: Theistik dan Pantheistik. Nilai yang abadi menurut Idealime Theistik ini bersifat transedental yaitu berada pada Tuhan. Sedangkan menurut Idealisme Pantheistik mengidentikan Tuhan dengan alam.

Untuk mewujudkan harmonisasi dalam kehidupan manusia, maka diatur dengan adanya kewajiban-kewajiban moral yang diturunkan dari pikiran tentang adanya metafisika. Sehingga menurut pandangan idealisme, nilai adalah absolut. Apa yang dikatakan baik dan buruk, benar, salah, cantik, ganteng, kurang ganteng, secara fundamental bersifat tetap, tidak berubah dari generasi ke generasi, tidak diciptakan oleh manusia dan nilai-nilai tersebut merupakan bagian dari alam semesta.

Di sisi lain, Plato juga mengemukakan bahwa kehidupan yang baik hanya mungkin terjadi dalam masyarakat yang baik dan ideal yang diperintah oleh "the Philosopher Kings", yaitu kaum intelektual, para ilmuwan atau cendekiawan ${ }^{7}$. Nampaknya pendapat beliau dapat disimpulkan bahwa jika

${ }^{6}$ Ibid.,h.45

${ }^{7}$ George $\mathrm{F}$ Kneller, Introduction to the Philosophy of Education (New York: Publishing John Wiley \& Sons, 1991), h. 33. (dalam http/:nurohcman-ceper.blogspot.com/2010) manusia tahu apa yang dikatakannya sebagai hidup yang baik dan berpedoman kepada suatu ide, mereka tidak akan berbuat hal-hal yang bertentangan dengan moral. Kejahatan terjadi karena mungkin orang tidak tahu bahwa perbuatan tersebut jahat. Kejahatan terjadi bukan hanya karena ada niat dari pelakunya tapi juga karena ada kesempatan.

Di dalam sebuah tulisannya, Sadulloh menjelaskan bahwa jika seseorang menemukan sesuatu yang benar, maka orang tersebut akan berbuat salah. Namun yang menjadi masalah adalah bagaimana hal itu dapat dilakukan jika manusia memiliki pandangan yang sangat berbeda dalam pikirannya tentang hidup yang baik. ${ }^{8}$

\section{Aliran-Aliran Filsafat Idealisme dan Tokohnya}

Secara historis, Plato merupakan salah seorang tokoh filsafat Yunani Kuno yang mempunyai pengaruh kuat dalam pengembangan ilmu pengetahuan. Ia juga dianggap sebagai pelopor filsafat idealisme yang mengagungkan nilai pengetahuan dan keadilan. ${ }^{9}$ Nampaknya pengaruh Plato ini begitu kuat terhadap pengembangan ilmu pengetahuan, sehingga aliran teologi dan filsafat Kristen pada umumnya sampai kurun waktu abad XIII bercorak Platonis ${ }^{10}$. Selain menciptakan dominasi yang kuat pada aliran teologi, Plato juga terkenal menjadi gurunya Aristoteles yang dianggap sebagai "Bapak Penalaran Deduktif". 11

\footnotetext{
${ }^{8}$ Sadulloh,U, Pengantar Filsafat pendidikan, (Bandung: Alpabeta, 2007) h. 99.

${ }^{9}$ Waini Rasyidin, Filsafat Pendidikan (dalam Ilmu dan Aplikasi Pendidikan), (Bandung: Pedagogiana Press, 2007), h. 10.

${ }^{10}$ Bisa kita lihat pada: Betrand Russel, Sejarah Filsafat Barat; Kaitannya dengan Kondisi Zaman Kuno Hingga Sekarang (terj), (Yogyakarta: Pustaka Pelajar, 2007), h. 141.

${ }^{11}$ Mantra, Ida Bagoes Filsafat Penelitian\& Metode Penelitian Sosial, (Yogyakarta: Pustaka Pelajar, 2004), h. 17.
} 
Konsep pengembangan ilmu pengetahuan yang digagas Plato dapat dibedakan menjadi 2 macam yaitu: pengetahuan yang bersifat inderawi (sensual) dan pengetahuan yang bersifat kejiwaan. Menurut Plato, pengetahuan yang diperoleh dengan menggunakan sarana inderawi hanya merupakan kesankesan yang bersifat sementara dan senantiasa berubah. Sementara pengetahuan yang diperoleh melalui proses perenungan kejiwaan dapat melahirkan kebijaksanaan dan keabadian nilai. $^{12}$

Paparan di atas memperlihatkan bahwa, selain konsep dalam pengembangan ilmu pengetahuan, Plato nampaknya memiliki sejumlah gagasan penting dalam filsafatnya, antara lain: gagasannya tentang Utopia, teori-teorinya tentang ide dan konsepnya tentang pengetahuan yang ternyata lebih bersumber dari ingatan dibanding dari persepsi. Berbagai gagasan penting Plato tersebut turut mempengaruhi pandangannya terhadap pentingnya pendidikan bagi individu, keluarga, kelompok dan lebih luas lagi yaitu bagi bangsa.

Selain itu, ada beberapa aliran idealisme filosofis yang turut menorehkan pengaruhnya dalam bidang pemikiran dan pendidikan. diantaranya adalah idealisme Jerman yang ditandai oleh tiga tahap perkembangan dalam pemikiran sosok tiga filosof. Tahapan pertama adalah J. G. Fichte yang berpandangan idealisme subjektif. Tahap selanjutnya adalah F. W. J. Schelling yang berpandangan idealisme objektif. Puncak idealisme Jerman tercapai di tangan G. W. F. Hegel yang

${ }^{12}$ Betrand Russel, Sejarah Filsafat Barat: Kaitannya dengan Kondisi Zaman Kuno Hingga Sekarang terj. (Yogyakarta: Pustaka Pelajar, 2007), h. 141 . pemikirannya disebut idealisme absolut sebagai hasil sintesis dari idealisme subjektif dan objektif. ${ }^{13}$

\section{Idealisme Subjektif}

Idealisme subjektif adalah aliran filsafat idealisme yang dipelopori oleh Fichte. Filsafat ini bertitik tolak pada ide manusia atau ide sendiri. Menurutnya dunia merupakan postulat subjek yang memutuskan. Alam dan masyarakat ini tercipta dari ide manusia. Segala sesuatu yang timbul dan terjadi di alam atau di masyarakat adalah hasil atau karena ciptaan ide manusia atau idenya sendiri, atau dengan kata lain alam dan masyarakat hanyalah sebuah ide/pikiran dari dirinya sendiri. Menurut filsafat ini segala, sesuatu yang tertangkap oleh sensasi/perasaan kita itu bukanlah materi yang riil dan ada secara objektif. Sesuatu yang bersifat materi misalkan buah jeruk, dianggapnya hanya sebagai sensasi-sensasi atau kumpulan perasaan/konsepsi tertentu yaitu perasaan/ konsepsi dari rasa jeruk, berat, harum, bentuk dsb. Dengan demikian teori ini menyangkal adanya materi yang ada secara objektif dan hanya mengakui adanya materi atau dunia yang riil didalam pikirannya atau idenya sendiri saja.

Kesimpulan yang dapat penulis nyatakan dari filsafat ini adalah, kecenderungan untuk bersifat egoistis "Aku-isme" yang hanya mengakui yang riil adalah dirinya sendiri yang ada hanya "Aku", segala sesuatu yang ada diluar selain "Aku" itu hanya sensasi atau konsepsi-konsepsi dari "Aku". Untuk berkelit dari tuduhan egoistis dan mengedepankan "Aku-isme, maka penulis menyatakan hanya Tuhan yang berada

${ }^{13}$ A. Pablo Iannone, Dictionary Of World Phylosophy, ( Newyork:Routledge, 2001), h. 251252. (dalam http/:nurohcmanceper.blogspot.com/2010) 
tanpa tergantung pada sensasi dan konsepsi-konsepsi.

\section{Idealisme Objektif}

Idealisme objektif adalah suatu aliran filsafat yang dimotori oleh Schelling. Pandangan idealismenya bertitik tolak dari ide universal, yaitu ide di luar ide manusia. Menurut idealisme objektif segala sesuatu baik yang ada di alam atau masyarakat luas adalah hasil dari ciptaan ide universal. Alam semesta yang kelihatan ini pada hakekatnya hanyalah intelegensi yang kelihatan.

Hemat penulis pandangan filsafat seperti ini pada dasarnya mengakui sesuatu yang bukan materi, yang ada secara abadi di luar manusia, sesuatu yang bukan materi itu ada sebelum dunia alam semesta ini ada, termasuk manusia dan segala pikiran dan perasaannya. Dalam pandangan lain, bentuknya yang agak primitif paradigma ini menyatakan jenisnya seperti dalam bentuk penyembahan terhadap pohon, batu, hewan dan benda-benda langit

Akan tetapi sebagai suatu sistem filsafat, pandangan dunia ini pertama-tama kali disistimatiskan oleh Plato (427-347 S.M). Menurut Plato dunia luar yang dapat di tangkap oleh panca indera kita bukanlah dunia yang riil, melainkan bayangan dari dunia "idea" yang abadi dan riil. Pandangan dunia Plato ini mewakili kepentingan kelas yang berkuasa pada waktu itu di Eropa yaitu kelas pemilik budak. Dan ini jelas nampak dalam ajarannya tentang masyarakat "ideal"14.

Pada jaman feodal, filsafat idealisme objektif ini mengambil bentuk yang dikenal dengan nama Skolastisisme, sistem filsafat ini memadukan unsur idealisme Aristoteles (384-322 S.M), yaitu bahwa dunia kita merupakan suatu tingkatan

\footnotetext{
${ }^{14}$ Betrand Russel, Sejarah Filsafat Barat:.
}

hirarki dari seluruh sistem hirarki dunia semesta, begitupun yang hirarki yang berada dalam masyarakat feodal merupakan kelanjutan dari dunia ke-Tuhanan. ${ }^{15}$

Jadi kesimpulannya, segala sesuatu yang ada dan terjadi di dunia ini maupun dalam alam semesta merupakan penjelmaan dari titah Tuhan atau perwujudan dari ide Tuhan. Filsafat ini pada masa itu memang lebih membela para bangsawan atau kaum feodal yang pada waktu itu merupakan tuan tanah besar di Eropa dan kekuasaan gereja sebagai "wakil" Tuhan di dunia ini.

\section{Idealisme Absolut}

Di masa modern sekitar abad ke-18 muncullah sebuah sistem filsafat idealisme objektif baru yang disebutnya dengan idealisme absolut, yaitu sistem yang dikemukakan oleh George.W.F Hegel (1770-1831 M). Filsafat ini pada dasarnya merupakan bentuk sintesis atas filsafat idealisme subjektif sedangkan filsafat idealisme objektif sebagai antithesis, kemudian disintesiskan dan diubah diberi nama menjadi idealisme absolute. Pemikiran seperti ini menurut kesimpulan penulis yaitu hakikat dunia ini adalah "ide absolut", yang berada secara absolut dan "objektif" didalam segala sesuatu dan tak terbatas pada ruang dan waktu. Ide absolut ini, dalam prosesnya menampakkan dirinya dalam wujud gejala alam, gejala masyarakat dan gejala pikiran.

Filsafat Hegel ini terlihat mewakili kelas borjuis Jerman yang pada waktu itu baru tumbuh dan masih lemah, kepentingan kelasnya menghendaki suatu perubahan sosial, menghendaki dihapusnya hak-hak istimewa kaum bangsawan. Hal ini tercermin dalam pandangannya yang

${ }^{15}$ Mantra, Ida Bagoes Filsafat Penelitian \& Metode Penelitian Sosial, (Yogyakarta: Pustaka Pelajar, 2004), h. 31. 
beranggapan bahwa sesuatu itu senantiasa berkembang dan berubah tidak ada yang abadi atau mutlak, termasuk juga kekuasaan kaum feodal. Akan tetapi, karena kedudukan dan kekuatannya masih lemah saat itu, maka mereka tidak berani terang-terangan melawan filsafat dan ajaran agama yang berkuasa ketika itu.

Nah, bagaimana kita memahami lebih mendalam pemikiran filsafat idealisme objektif ini? Tentu dapat kita jumpai dalam kehidupan sehari-hari dengan berbagai macam bentuk. Misalnya saja, perwujudan paling umum antara lain dalam bentuk formalisme dan doktrinerisme. Kaum doktriner dan formalis secara buta mempercayai dalil-dalil atau teori sebagai kekuatan yang maha kuasa, sebagai obat manjur buat segala macam penyakit, sehingga dalam melakukan tugas-tugas atau menyelesaikan persoalanpersoalan praktis mereka tidak bisa berfikir atau bertindak secara rasional berdasarkan situasi yang kongkret.

\section{Implementasi Filsafat Idealisme dalam Pendidikan}

Filsafat Idealisme merupakan salah satu filsafat yang dikembangkan dalam pendidikan. Dalam bidang pendidikan, manusia khususnya peserta didik adalah subyek pendidikan. Pendidikan perlu mengetahui secara jelas tentang manusia atau peserta didik tersebut. Dengan sendirinya muncullah pertanyaanpertanyaan mengenai apa manusia dan apa peserta didik. Karena jawaban-jawaban pertanyaan tersebut bersifat abstrak maka di sinilah diperlukan adanya filsafat dalam pendidikan $^{16}$

Filsafat Idealisme sebagai salah satu aliran filsafat memiliki pengaruh yang

\footnotetext{
${ }^{16}$ Imam Barnadib, Filsafat Pendidikan, (Yogyakarta: Adicita, 2002), h. 5-6.
}

besar dalam implementasi pendidikan. Kenyataan dan kebenaran sesuatu, bagi idealisme pada hakikatnya sama kualitasnya dengan hal-hal yang bersifat spiritual atau ide-ide. Idealisme memiliki keterkaitan dengan konsep-konsep abadi (ideas), seperti kebenaran, keindahan dan kemuliaan. Idealisme pada intinya adalah suatu penekanan pada realitas ide atau gagasan, pemikiran atau akal-pikir yang dijadikan sebagai dasar atau pijakan hal-hal yang bersifat materi atau material. Pengaruh idealisme terhadap pemikiran dan pendidikan dapat dilihat dari lahirnya tokoh-tokoh seperti William T. Harris, seorang tokoh aliran pendidikan idealisme yang sangat berpengaruh di Amerika Serikat, juga lahirnya Herman Harrell Horne, seorang filosof yang mengajar filsafat beraliran idealisme lebih dari 33 tahun di Universitas New York. ${ }^{17}$

Kita dapat menilai bahwa filsafat idealisme sangat concern tentang keberadaan sekolah/lembaga pendidikan. Aliran inilah satu-satunya yang melakukan oposisi secara fundamental terhadap filsafat naturalisme. Pendidikan harus terus eksis sebagai lembaga untuk proses pemasyarakatan manusia sebagai bentuk dari kebutuhan spiritual dan tidak sekadar kebutuhan alam semata. Gerakan filsafat idealisme pada abad ke-19, secara khusus mengajarkan kepada kita tentang kebudayaan manusia dan lembaga kemanusiaan sebagai ekspresi dari realitas spiritual.

Menurut penulis, terdapat implikasi filsafat pendidikan idealisme yang dapat disebutkan diantaranya sebagai berikut: (1) Tujuan: untuk membentuk karakter, mengembangkan bakat atau kemampuan dasar, serta kebaikan sosial, (2) Kurikulum:

${ }^{17}$ George George R., Filsafat Pendidikan (terj), (Yogyakarta: Gama Media, 2007), h. 67. 
pendidikan liberal untuk pengembangan kemampuan rasional dan pendidikan praktis untuk memperoleh pekerjaan, (3) Metode: diutamakan metode dialektika, tetapi metode lain yang efektif dapat pula dimanfaatkan, (4) Peserta didik bebas untuk mengembangkan kepribadian, bakat dan kemampuan dasarnya, (5) Pendidik bertanggung jawab dalam menciptakan lingkungan pendidikan melalui kerja sama dengan semua unsur yang ada di alam.

Dalam pandangan Tatang Syaripudin (2008), ${ }^{18}$ implikasi filsafat idealisme dalam pendidikan dapat dirumuskan sebagai berikut:

\section{Tujuan Pendidikan}

Tujuan utama dari pendidikan idealis adalah untuk membantu pribadi pelajar/ peserta didik untuk mencapai kebijaksanaan, yakni bersatu dengan keabsolutan. Untuk mencapai kebijaksanaan setiap manusia harus mengenal dan diperkenalkan padanya. Jadi pada dasarnya, tujuan pendidikan idealis adalah untuk berperan dalam proses konversi pada kebijaksanaan, kebenaran dan keindahan. Maka, setiap individu pelajar memiliki potensi yang menyatu dengan struktur idealnya. Pendidikan bertujuan untuk membantu dalam penyingkapan dan pengembangan potensipotensi tersebut.

Berdasarkan pada asumsi bahwa keabsolutan disingkap melalui penyingkapan bertahap atas sejarah dan kebudayaan manusia, Idealis memandang bahwasannya pelajar dihadapkan pada kemungkinan kemungkinan budaya yang inheren pada warisan budayanya. Seseorang yang sedang memasuki proses perkembangannya memahami bahwa hubungan antara manusia tertentu dengan

\footnotetext{
${ }^{18}$ Tatang Syarifudin, Pengantar Filsafat Pendidikan (Bandung: Percikan Ilmu, 2008), h.45
}

manusia pada umumnya adalah bersifat kekal. Sebagai institusi sosial, sekolah/ lembaga pendidikan mengolah perkembangan baik personalitas individu manusia maupun sosial.

Dengan kata lain pendidikan bertujuan untuk membantu perkembangan pikiran dan diri pribadi siswa. Namun perlu diingat, karena bakat manusia berbeda-beda maka pendidikan yang diberikan kepada setiap orang harus sesuai dengan bakatnya masing-masing.

Menurut Imam Barnadib, Pendidikan yang menitikberatkan pada idealisme akan merumuskan tujuan pendidikan sebagai pencapaian manusia yang berkepribadian mulia dan memiliki taraf hidup kerohanian yang tinggi dan ideal. ${ }^{19}$

Idealisme memiliki tujuan pendidikan yang pasti dan abadi, di mana tujuan itu berada di luar kehidupan manusia, yaitu manusia yang mampu mencapai dunia cita dan cinta yang di dalamnya penuh dengan kemesraan, manusia yang mampu mencapai dan menikmati kehidupan abadi yang berasal dari Tuhan.

Kontribusi yang besar idealisme tehadap perkembangan pendidikan adalah pandangannya yang menempatkan manusia sebagai bagian dari alam spiritual, yang memiliki pembawaan spiritual sesuai potensinya. Oleh karena itu, pendidikan harus mengajarkan hubungan antara peserta didik dengan bagian alam spiritual. Pendidikan harus menekankan kesesuaian batin antara peserta didik dengan alam semesta. Pendidikan merupakan pertumbuhan ke arah tujuan pribadi manusia yang ideal. Menyinggung sikap pendidik, bagi idealisme pendidik harus mewujudkan sedapat mungkin karakter yang terbaik, sehingga anak harus

15. 
dipandang sebagai tujuan, bukan sebagai alat.

Oleh karena itu, tujuan pendidikan menurut paham idealisme terbagi atas tiga hal, yaitu: tujuan untuk individual, tujuan untuk masyarakat dan campuran antara keduanya. Pendidikan idealisme untuk individual antara lain bertujuan agar anak didik bisa menjadi kaya dan memiliki kehidupan yang bermakna, memiliki kepribadian yang harmonis dan penuh warna, hidup bahagia, mampu menahan berbagai tekanan hidup dan pada akhirnya diharapkan mampu membantu individu lainnya untuk hidup lebih baik.

Adapun tujuan pendidikan idealisme bagi kehidupan sosial adalah perlunya persaudaraan sesama manusia. Karena dalam spirit persaudaraan terkandung suatu pendekatan seseorang kepada yang lain. Seseorang tidak sekadar menuntut hak pribadinya, namun hubungan manusia yang satu dengan yang lainnya terbingkai dalam hubungan kemanusiaan yang penuh pengertian dan rasa saling menyayangi. Sedangkan tujuan secara sintesis dimaksudkan sebagai gabungan antara tujuan individual dengan sosial sekaligus, yang juga terekspresikan dalam kehidupan yang berkaitan dengan Tuhan.

\section{Kurikulum Pendidikan}

Para Idealis memandang kurikulum sebagai manifestasi dari subjek materi intelektual yang bersifat gagasan-gagasan dan konsep-konsep. Aneka ragam sistem konsep ini menjelaskan dan didasarkan pada manifestasi-manifestasi utama dari nilai-nilai yang absolut. Oleh karenanya, seluruh sistem konsep berkulminasi dan tergabung dalam satu konsep, ide yang menyatu dan integral.

Sistem-sistem konsep yang lahir dari keabsolutan yang universal disingkap oleh manusia dengan menyingkap sejarah dan warisan budayanya. Kurikulum Idealis dapat dilihat sebagai suatu hierarki yang kebanyakan ditempati oleh disiplin-disiplin umum, seperti filsafat dan theologi yang membahas tentang hubungan-hubungan yang paling mendasar dan utama terhadap Tuhan. Berdasarkan pada prinsip hierarki tersebut, keutamaan dari suatu subjek dilihat dari segi generalitas subjek tersebut. Subjek materi yang lebih general adalah subjek materi yang bersifat lebih abstrak dan melampaui batasan-batasan ruang, waktu dan keadaan. Oleh karena itu, subjek-subjek tersebut memiliki kemampuan untuk mentransfer pada ragamragam situasi yang luas. Sejarah dan sastra misalnya, menempati posisi yang tinggi dalam hierarki kurikulum tersebut. Di samping stimulus kognitifnya, ilmu sejarah dan sastra terbungkus dalam nilai-nilai.

Dengan demikian, sejarah dan autobiografi dapat dikatakan sebagai sumber bagi keteladanan dan kepahlawanan moral dan budaya. Dimensi sejarah dapat dipandang sebagai sebuah rekaman atas penyingkapan keabsolutan sepanjang waktu dan proses historis manusia, khususnya bagi orang-orang yang terlibat dalam dimensi kepahlawanannya.

Pernyataan di atas menunjukkan bahwa kurikulum yang digunakan dalam pendidikan yang beraliran idealisme harus lebih memfokuskan pada isi yang objektif. Pengalaman haruslah lebih banyak daripada pengajaran yang texbook, agar supaya pengetahuan dan pengalamannya senantiasa aktual. Kurikulum pendidikan idealisme berisikan pendidikan liberal dan pendidikan vokasional/praktis. Pendidikan liberal dimaksudkan untuk pengembangan kemampuan-kemampuan rasional dan moral peserta didik. Pendidikan vokasional dimaksudkan untuk pengembangan kemampuan diri atau yang disebut dengan istilah life skill (kecakapan hidup).

Pada saat yang sama, sumber-sumber sejarah dan sastra ini dapat diserap secara 
emosional dan digunakan sebagai dasar bagi konstruksi keteladanan dan nilai-nilai. Edukasi nilai, berdasarkan konsepsi Idealis, mensyaratkan agar peserta didik diperkenalkan pada teladan dan contohcontoh yang baik agar keteladan tersebut dapat ditiru dan dikembangkan olehnya.

\section{Metode Pendidikan}

Sejak idealisme sebagai bagian dari filsafat pendidikan lalu menjadi keyakinan bahwa realitas adalah pribadi, maka mulai saat itu terus dipahami tentang perlunya pembelajaran secara individual. Pola pendidikan yang diajarkan fisafat idealisme berpusat dari idealisme. Pembelajaran tidak sepenuhnya terpusat kepada peserta didik atau materi pelajaran, juga bukan masyarakat, melainkan berpusat pada idealisme.

Dalam proses pembelajaran, tidak cukup mengajarkan peserta didik tentang bagaimana berpikir, tetapi yang penting justru apa yang siswa pikirkan menjadi kenyataan dalam perbuatan. Metode mengajar hendaknya mendorong siswa untuk memperluas cakrawala, mendorong bergerak reflektif, mendorong pilihanpilihan moral pribadi, memberikan keterampilan-keterampilan yang logis, memberikan kesempatan menggunakan pengetahuan untuk mengatasi masalahmasalah moral dan sosial, meningkatkan minat terhadap konten mata pelajaran dan mendorong peserta didik untuk menerima nilai-nilai peradaban manusia.

Salah satu model pendidikan idealisme yaitu bahwa peserta didik harus didekati (approach) secara khusus. Sebab pola pendekatan dipandang sebagai cara yang cukup efektif dalam memberikan materi pembelajaran dan dalam membentuk karakter manusia. Penulis cenderung dengan sebuah prinsip pendidikan bahwa "Para guru dan atau dosen tidak boleh berhenti hanya di tengah sistem klasikal atau tidak mengawasi satu persatu peserta didik. Seorang guru atau dosen sebaiknya masuk ke dalam pemikiran terdalam dari peserta didik, bahkan bila perlu ia berkumpul hidup bersama para peserta didik.

Meskipun seorang peserta didik telah memiliki ketertarikan terhadap pribadinya, namun tidak semua proses belajar berlangsung dengan mudah. Peserta didik sangat mungkin terperdaya akan penampilan dunia dan mencari jawabannya dengan sesuatu yang sebenarnya tidak berhubungan dengan perkembangan pribadinya. Pada saat seperti inilah, seorang guru dan dosen menjalankan perannya untuk mengarahkan kembali peserta didik pada kebenaran. Setelah melakukan usaha dan mengaplikasikannya pada disiplin pribadi, bisa jadi peserta didik lebih memiliki ketertarikan pada tugas-tugas pembelajaran. Sekali lagi, warisan budaya dapat berpengaruh pada kejiwaannya. Semakin banyak warisan budaya yang dipahami oleh peserta didik semakin banyak pula kemungkinan ketertarikan yang dimiliki olehnya. Semakin banyak ketertarikan yang dimiliki semakin besar kemungkinan untuk mengembangkan diri.

Dalam hal ini, M. Jumali menjelaskan bahwa metode pendidikan Idealis dirancang untuk menstimulasi intuisi dan eksplorasi introspeksi diri (intuitive and introspective self eksploration) secara mandiri pada proses perkembangan yang berjalan dari dalam ke luar. ${ }^{20}$ Namun penulis berpikir bahwa sebenarnya tidak ada suatu metode pun yang sangat efektif yang digunakan secara khusus untuk menstimulasi peserta didik. Artinya semua metode hendaklah disesuaikan dengan materi pembelajaran dan kondisi yang ril. Oleh karenanya seorang guru atau dosen Idealis harus mampu menguasai berbagai macam metode

${ }^{20}$ M. Jumali, dkk, Landasan Pendidikan, (Surakarta:Muhammadiyah University Press, 2008), h. 105. 
dan menggunakan metode tertentu yang efektif dan cocok untuk menjamin hasil yang diharapkan.

Meskipun tidak ada metode tertentu yang dapat dispesifikkan, namun ada metode yang selalu diterapkan yaitu metode dialog Socratik. Metode ini lazimnya lebih diprioritaskan dalam situasi pembelajaran Idealis. Dialog Sokratik adalah suatu proses di mana orang dewasa berperan sebagai stimuler (pemberi rangsangan) bagi kesadaran dan gagasangagasan peserta didik. Pendidik menyiapkan pertanyaan-pertanyaan yang mengacu pada masalah-masalah yang berhubungan dengan kehidupan manusia. Ketika dialog Socratik diterapkan pada suatu kelas, pendidik harus mampu menggunakan proses tersebut yang dapat menciptakan suatu kondisi berpikir yang berkembang di mana para peserta didik tertarik untuk berpartisipasi.

Salah satu kunci metode socratik yaitu keahlian bertanya yang harus dimiliki oleh sang pendidik. Metode tersebut tidak hanya sekedar pengulangan sekilas terhadap materi pembelajaran yang telah diberikan, namun hapalan terhadap materi merupakan tahapan penting menuju dialog yang berkualitas.

Siapapun orangnya, pembaca terlebih dahulu memahami buku sebelum melakukan diskusi. Tahap ini menjadi penting karena ketika seorang pendidik telah membuka suatu diskusi, ia harus memastikan tidak adanya kesalahan informasi dan tidak mengajukan opiniopini yang tidak refresentatif. Mengapa? Sebab agar tidak menyamarkan esensi materi yang penting dalam proses pembelajaran.

Selain metode di atas, masih ada metode yang diperkenalkan oleh idealisme yakni metode Imitasi terhadap keteladanan. Seperti apa metode ini? Mari kita baca. Para peserta didik diperkenalkan pada pelajaran-pelajaran yang berharga dari para tokoh-tokoh teladan dalam berbagai bidang, seperti sejarah, sastra, religi, biografi, tokoh pendidikan dan filsafat. Peserta didik dianjurkan untuk mempelajari suri teladan dari seorang tokoh sebagai sumber-sumber nilai. Dan jangan lupa bahwa dalam hal ini seorang pendidik juga berperan sebagai sumber langsung keteladanan karena ia adalah personifikasi dari nilai-nilai luhur yang tercermin dalam kultur dan kehidupan masyarakat. Selain sebagai figur berdasarkan kompetensinya di bidang materi dan pedagogi, ia juga harus mampu menjadi pribadi yang estetis yang layak dijadikan suri tauladan bagi para peserta didiknya. Inilah yang dimaksud dengan mengimitasi keteladanan, yakni dengan menerapkan nilai-nilai keteladanan tersebut dalam kehidupan pribadi peserta didik. Namun perlu diingat, bahwa meneladani bukan berarti meniru, melainkan suatu pancaran kebijaksanaan pada kehidupan pribadinya.

\section{Peran Pendidik Terhadap Peserta Didik}

Bagaimana peran seorang pendidik dalam membentuk karakter dan keilmuan peserta didik? Dalam hubungan pendidikpeserta didik, peran sentral seorang pendidik lebih diutamakan. Sebagai pribadi yang dewasa, pendidik Idealis seharusnya adalah seseorang yang mapan dalam perspektif ilmu, sosial dan budaya. Dia harus mampu menjadi pribadi yang integral yang mampu menjalani berbagai peran dalam kehidupannya di suatu komunitas yang memiliki nilai-nilai kehidupan.

Penulis cenderung mengatakan bahwasannya peserta didik adalah pribadi yang belum dewasa yang terus mencari 
perspektif apapun yang akan dia hadapi. Hal ini bukan berarti bahwa kepribadian peserta didik adalah sesuatu yang harus dimanipulasi oleh pendidik. Hanya saja dapat dikatakan bahwa peserta didik berkembang menuju kedewasan, menuju suatu perspektif dalam kepribadiannya berdasarkan atas kemampuannya menggunakan nalar dan akalnya sendiri. Pendidik harus menghormati peserta didiknya dan memahami perannya dalam membantu mereka merealisasikan keutuhan kepribadiannya. Oleh karena itu, pendidik haruslah menerapkan nilai-nilai, mencintai peserta didik, menyenangkan dan seorang pribadi yang antusias, semangat dan penuh keikhlasan dalam mendidik.

Dari uraian di atas, penulis menyimpulkan bahwa ada beberapa kecakapan yang harus dimiliki seorang pendidik, diantaranya: 1) Mampu mempersonifikasikan budaya dan realita, 2) Mampu memahami kepribadian peserta didiknya, 3) Mampu menyatukan beberapa keahlian dengan antusias tinggi, 4) Menjadi seorang teman bagi peserta didiknya, 5) Mampu membangkitkan minat belajar, 6) Sadar akan signifikansi akhlak dalam pekerjaannya. Kecakapankecakapan yang penulis sebutkan di atas, hanyalah bagian kecil yang harus melekat pada seorang pendidik. Tentu masih banyak hal-hal lain yang harus dimiliki seorang pendidik dalam menjalankan kewajibannya sebagai pendidik.

Dari sisi ini wajarlah ketika filsafat idealisme mempunyai harapan yang tinggi dari para pendidik. Olah karenanya, selain kecakapan-kecakapan di atas, pendidik harus mempunyai keunggulan lain yakni keunggulan secara moral dan intelektual. Mungkin tidak salah kalau penulis cantumkan sebuah motto hidup pendidik:
"Unggul Dalam Ilmu, Mulia Dalam Akhlak".

Agar proses pendidikan dapat berjalan dengan baik dan berhasil mencapai tujuannya, maka peran pendidik sangatlah penting. Didalam sistem pembelajaran yang menganut aliran idealisme, pendidik berfungsi sebagai berikut ${ }^{21}$ : (1) pendidik adalah personifikasi dari kenyataan si peserta didik, (2) pendidik berperan sebagai spesialis dalam suatu ilmu pengetahuan dari peserta didik, (3) pendidik berperan sebagai aktor yang harus menguasai teknik mengajar secara baik, (4) pendidik berperan menjadi pribadi terbaik, sehingga disegani oleh peserta didik, (5) pendidik berperan menjadi teman dari peserta didik dan bukan menjadi teman selingkuh, (6) pendidik berperan menjadi pembangkit gairah peserta didik dalam belajar, (7) pendidik berperan menjadi "artis idola" peserta didik, (8) pendidik berperan menjadi figur dalam beribadah, sehingga menjadi insan kamil yang bisa menjadi teladan para peserta didiknya, (9) pendidik berperan sebagai komunikator dengan peserta didik, (10) pendidik adalah siswa yang tak pernah berhenti belajar, (12) pendidik sebagai bagian yang merasa bahagia jika anak didiknya berhasil, (13) pendidik haruslah moderat dalam mengembangkan demokrasi berpikir.

\section{E. Penutup}

Idealisme adalah sistem filsafat dari Plato dan dikembangkan oleh para pengikutnya yang menekankan pentingnya keunggulan pikiran (mind), roh (soul), jiwa (spirit) atau ide dari pada hal-hal yang bersifat kebendaan atau material. Pandangan-pandangan umum yang

${ }^{21}$ Nur Rachman, Fungsi Guru Dalam Aliran Idealisme, dalam http//nurachmancaper.blogspot.com/2010 
disepakati oleh para filsuf idealisme, yaitu: Jiwa (soul) manusia adalah unsur yang paling penting dalam hidup, sedangkan hakikat akhir alam semesta pada dasarnya adalah nonmaterial.

Pokok-Pokok pikiran Idealisme terdiri dari pandanganya tentang metafisika, epistimologi dan aksiologi. Pandangan metafisika idealisme hanya melihat realitas spiritual, mental atau rohani yang nyata dan tidak berubah. Alam semesta adalah ekspresi dari sebuah kecerdasan yang sangat umum dari pikiran universal.

Sedangkan epistimologi idealisme menegaskan bahwa proses mengetahui terjadi dalam pikiran, manusia memperoleh pengetahuan melalui berfikir dan intuisi (gerak hati). Beberapa filsuf percaya bahwa pengetahuan diperoleh dengan cara mengingat kembali (semua pengetahuan adalah sesuatu yang diingat kembali). Sehinggga mengetahui adalah memikirkan kembali gagasan laten, yakni gagasan yang kekal dalam alam ide.

Adapun aksiologi idealisme menempatkan nilai bersifat mutlak dan abadi. Nilai-nilai yang abadi tersebut menurut idealime theistik berada dalam kekuasaan mutlak Tuhan. Sedangkan Idealisme Pantheistik mengidentikan Tuhan dengan alam. Sementara itu, dalam perjalanan pemikirannya, filsafat idealisme berkembang menjadi beberapa aliran sesuai dengan pandangan para pengikutnya, yaitu idealisme subjektif ((Fichte), Idealisme Objektif (Schelling) dan Idealisme absolute (Hegel).

$$
\text { Refleksi pendidikan filsafat }
$$

idealisme dalam praktek pendidikan adalah terlaksananya proses pendidikan dengan mendasarkan formulasi sebagai berikut: (1) Tujuan yaitu: untuk membentuk karakter, mengembangkan bakat atau kemampuan dasar, serta kebaikan sosial, (2) Kurikulum: pendidikan liberal untuk pengembangan kemampuan rasional dan pendidikan praktis untuk memperoleh pekerjaan, (3) Metode: diutamakan metode socratik/dialektika, tetapi metode lain yang efektif dapat pula dimanfaatkan, (4) Peserta didik bebas untuk mengembangkan kepribadian, bakat dan kemampuan dasarnya, (5) Pendidik bertanggung jawab dalam menciptakan lingkungan pendidikan melalui kerja sama dengan lingkungan, peserta didik dan alam.

\section{DAFTAR PUSTAKA}

Barnadib, Imam, Filsafat Pendidikan, Yogyakarta: Adicita, 2002.

Iannone, A. Pablo, Dictionary of World Phylosophy, London \& New York: Routledge, 2001.

Jumali, M dkk, Landasan Pendidikan, Surakarta: Muhammadiyah University Press, 2008.

Kartanegara, Mulyadhi, Menembus Batas Waktu, Panorama Filsafat Islam, Sebuah Refleksi Autobiografis, Bandung: Mizan, 2005.

Kneller, George F. Introduction to the Philosophy of Education, New York: Publishing John Wiley\& Sons, 1991.

Knight, George R. Filsafat Pendidikan (terj), Yogyakarta: Gama Media, 2007.

Long, Wilbur, Idealism, dalam Dagobert D. Runes, The Dictionary of Phylosophy, New York: Phylosophical Library, tt.

Mantra, Ida Bagoes Filsafat Penelitian\& Metode Penelitian Sosial, Yogyakarta: Pustaka Pelajar, 2004. 
Ornstein, Allan C \& Daniel U, $A n$ Introduction To The foundations of Education, Boston: Houghton Mifflin Company,1985.

Rachman, Nur. Fungsi Guru dalam Aliran Idealism dalam http//nurrachmanceper.blogspot.com/2010, diunggah pada 3 Mei 2010.

Russel, Betrand Sejarah Filsafat Barat; Kaitannya dengan Kondisi Zaman Kuno Hingga Sekarang (terj), Yogyakarta: Pustaka Pelajar, 2007.

Sadulloh,U, Pengantar Filsafat pendidikan, Bandung: Alpabeta, 2007.

Suriasumantri, Jujun S. Ilmu Dalam Perspektif, Jakarta: PT Gramedia, 1982.

Syaripudin, Tatang, Pengantar Filsafat Pendidikan, Bandung: Percikan Ilmu, 2008.

Rasyidin, Waini, Filsafat Pendidikan (dalam Ilmu dan Aplikasi Pendidikan), Bandung: Pedagogiana Press, 2007. 
